\title{
Bilateral acute depigmentation of the iris: a case report
}

\section{Despigmentação aguda bilateral da íris: um relato de caso}

Débora Raquel Rigon Narciso Fachin ${ }^{1}$, Maria Fernanda de Paula Prestes ${ }^{2}$, Angelino Julio Carielloํ․ Mário Junqueira Nóbrega ${ }^{1,3}$

\begin{abstract}
Bilateral acute depigmentation of the iris (BADI) is a new clinical entity of unknown etiology and is characterized by bilateral, symmetrical, and simultaneous depigmentation of the iris with focal or diffuse stromal atrophy; this condition generally has a good prognosis. We present a case of a 26 -year-old woman who noted a spontaneous change in the iris color in both eyes in the last 2 months. The ophthalmological findings were atrophy of the iris stroma and pigmentation of the trabecular meshwork, without affecting the pigmented epithelium of the iris. Her intraocular pressure was normal and the visual acuity was 20/20 in both eyes.
\end{abstract}

Keywords: Iridocyclitis; Iris; Iris diseases; Pigment epithelium of eye; Pigmentation disorders; Eye color

\section{RESUMO}

A despigmentação aguda bilateral da íris (DABI) é uma nova entidade clínica caracterizada pela despigmentação bilateral, simétrica e simultânea da íris, com atrofia focal ou difusa do seu estroma, geralmente com bom prognóstico. Apresentamos o caso de uma mulher de 26 anos de idade que procurou atendimento médico em nosso serviço com queixa de mudança espontânea na cor da íris de ambos os olhos nos últimos dois meses. Os achados oftalmológicos observados durante o exame clínico foram atrofia do estroma da íris e pigmentação da malha trabecular, sem afetar o epitélio pigmentado da íris. A pressão intraocular era normal e acuidade visual de 20/20 em ambos os olhos.

Descritores: Iridociclite; Iris; Doenças da íris; Epitélio pigmentado ocular; Transtornos da pigmentação; Cor de olho

\section{INTRODUCTION}

Bilateral acute depigmentation of the iris (BADI) is a rare disorder with unknown etiology. It was described for the first time in Turkey in $2006^{(1)}$. It occurs more frequently in middle-aged women and is characterized by asymptomatic, bilateral, symmetrical, and simultaneous iris depigmentation with focal or diffuse stromal atrophy ${ }^{(2,3)}$.

Although BADI is not usually associated with atrophy of the iris pigmented epithelium, pigment dispersion in the anterior chamber and pigment deposition in the trabecular meshwork have been reported. The prognosis is generally good and repigmentation can occur spontaneously ${ }^{(3-5)}$

Here we describe a case of BADI and discuss its main clinical aspects and differential diagnosis.

\section{CASE REPORT}

A 26-year-old emmetropic woman presented to our clinic after noticing spontaneous iris color change over the past 2 months. Her personal and family medical histories were negative for eye diseases.

Visual acuity was 20/20 and intraocular pressure was $12 \mathrm{mmHg}$ (at 10:00 am) in both eyes. Biomicroscopy revealed extensive bilateral stromal iris atrophy (Figures 1 and 2). The transillumination test was negative and the lens showed no abnormalities. Gonioscopy showed an open iridocorneal angle with a heavily pigmented trabecular meshwork. The dilated fundus examination was unremarkable in both eyes.
Her serology tests were negative for herpes simplex IgM (herpes simplex IgG positive), hepatitis B and C, and toxoplasmosis. The tuberculin sensitivity test was non-reactive $(0 \mathrm{~mm})$.

There was no detectable change in the clinical examination after 10 months of follow-up, with maintenance of the pattern of bilateral stromal iris atrophy without any transillumination defects (Figures 3 and 4).

\section{DISCUSSION}

BADI is a rare disease with unknown etiology and pathophysiology. The largest published case series of BADI enrolled 26 patients and revealed a previous history of upper respiratory tract infection in $35.8 \%{ }^{(5)}$. The authors also suggested an association of BADI with cytomegalovirus infection ${ }^{(5)}$. Another study suggested a possible relationship with the herpes simplex virus and varicella zoster virus ${ }^{(1)}$. Non-infectious etiologies like iris ischemia and neurotrophic mechanisms have also been proposed (3); however, no causative agents have been confirmed yet.

Despite the lack of clinical change after 10 months of follow-up in the case described in this report, other studies have shown that there could be spontaneous resolution over time ${ }^{(3,5)}$.

The differential diagnosis of BADI includes Fuchs heterochromic uveitis, herpetic iridocyclitis, pigment dispersion syndrome, and pseudoexfoliation syndrome(6).
Funding: No specific financial support was available for this study.

Disclosure of potential conflicts of interest: None of the authors have any potential conflict of interest to disclose.

Corresponding author: Débora Raquel Rigon Narciso Fachin. Rua Camboriú, 35 - Joinville, SC 89216-222 - Brazil - E-mail: deboranarciso@hotmail.com 


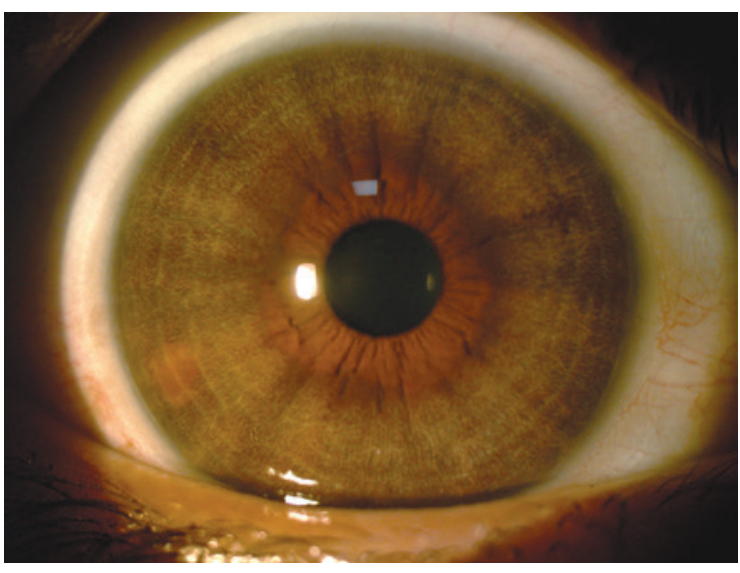

Figure 1. Diffuse bilateral iris atrophy in the right eye.

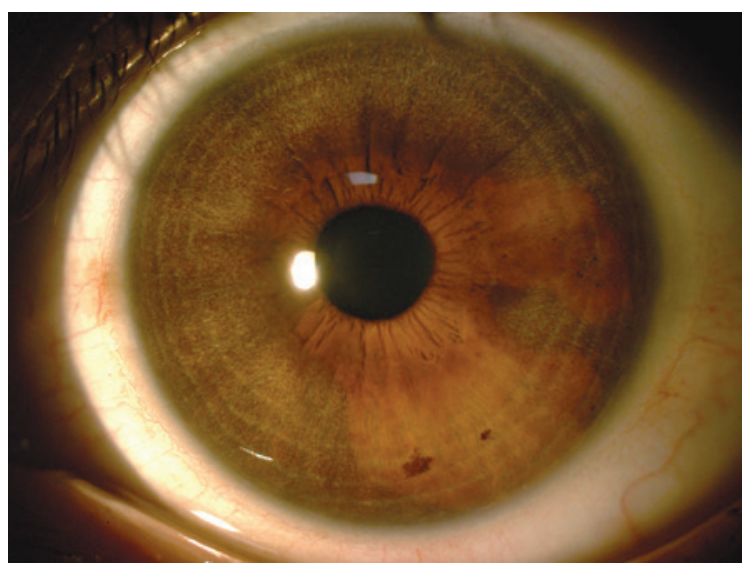

Figure 2. Diffuse bilateral iris atrophy in the left eye.

Fuchs heterochromic uveitis is bilateral only in 5\%-10\% of cases and generally presents with stellate keratic precipitates, mild intraocular inflammation, and cataract ${ }^{(5)}$. Herpetic iridocyclitis generally manifests as a unilateral hypertensive acute anterior uveitis in patients with decreased corneal sensitivity. A subsequent positive transillumination test may be observed as a sequela of the posterior iris pigment epithelium atrophy ${ }^{(7)}$

The pigment dispersion and pseudoexfoliation syndromes exhibit typical bilateral, irreversible, posterior iris pigment epithelium defects and a positive transillumination test on slit lamp examination ${ }^{(8)}$.

The diagnosis of BADI is based on clinical features and may be challenging due to its rarity and the paucity of noted signs and symptoms. Nonetheless, the clinical findings described in this case were different from those observed in all the entities mentioned above. We believe that the prevalence of this disease may be higher than previously thought and that documenting periodical iris images may help in the diagnosis of suspected cases.

Maestrini et al. ${ }^{(2)}$ described the first Brazilian case of this disease; however, as pointed by experts in this pathology in a letter to the editor ${ }^{(9)}$, deeper analysis of the case demonstrated that the characteristics were closer to another pathological condition called bilateral acute iris transillumination (BAIT). This disorder usually shows atonic dilated pupils and diffuse iris transillumination defects and has a

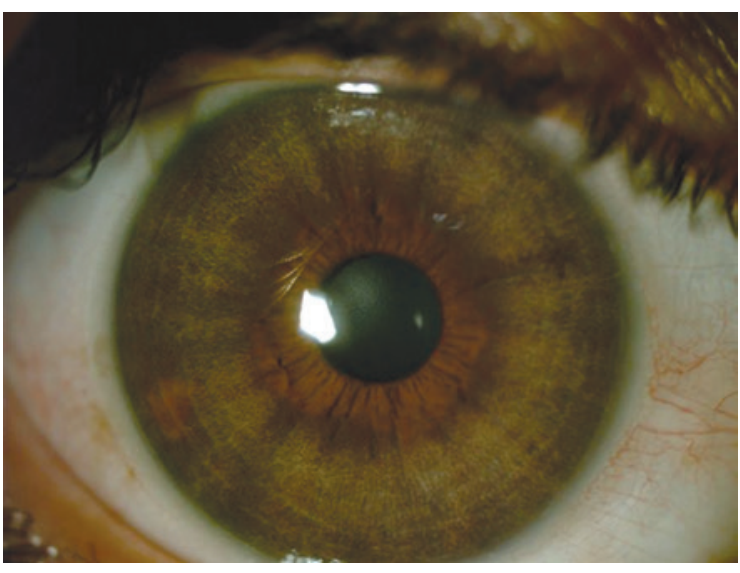

Figure 3. Aspect of the right eye after 10 months.

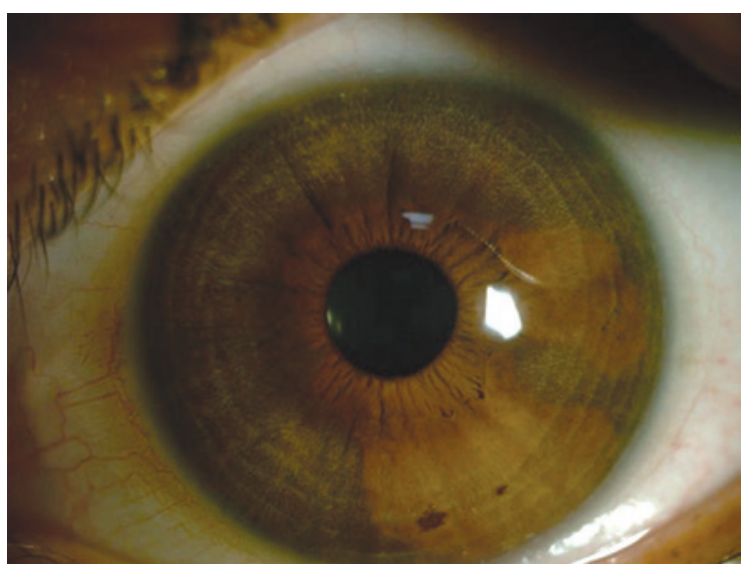

Figure 4. Aspect of the left eye after 10 months.

higher incidence of IOP elevation ${ }^{(10)}$. Thus, we believe that our report is the first described case of BADI in Brazil.

\section{REFERENCES}

1. Tugal-Tutkun I, Urgancioglu M. Bilateral acute depigmentation of the iris. Graefe's Arch Clin Exp Ophthalmol. 2006;244(6):742-6.

2. Maestrini HA, Maestrini AA, Machado DO, Santos DV, Almeida HG. Bilateral acute depigmentation of the iris (BADI): first reported case in Brazil. Arq Bras Oftalmol. 2013; 76(1):42-4. Comment in: Arq Bras Oftalmol. 2014;77(3):201.

3. Barraquer F, Mejía LF. Bilateral acute depigmentation of the iris: first report on the American continent and 5 years follow-up of two patients. J Emmetropia [Internet] 2012[cited 2014 Jun 21];3(3):118-22. Available from: http://www.journalofemmetropia. org/2171-4703/v3n3/v3-3-02.pdf

4. Portmann A, Gueudry J, Siahmed K, Muraine M. [Bilateral acute depigmentation of the iris syndrome]. J Fr Ophthamol. 2010;34(5):309-12.

5. Tugal-Tutkun I, Araz B, Taskapili M, Akova YA, Yalniz-Akkaya Z, Berker N, et al. Bilateral acute depigmentation of the iris: report of 26 new cases and four-year follow-up of two patients. Ophthalmology. 2009;16(8):1552-7.

6. Goktas A, Goktas S. Bilateral acute depigmentation of the iris first misdiagnosed as acute iridocyclitis. Int Ophthalmol. 2011;31(4):337-9.

7. Siverio Junior CD, Imai YD, Cunningham ET Jr. Diagnosis and management of herpetic anterior uveitis. Int Ophthalmol Clin. 2002;42(1):43-8.

8. Niyadurupola N, Broadway DC. Pigment dispersion syndrome and pigmentary glaucoma - a major review. Clin Experiment Ophthalmol. 2008;36(9):868-82.

9. Gonul S, Bozkurt B. Bilateral acute depigmentation of the iris (BADI): first reported case in Brazil. Arq Bras Oftalmol. 2014;77(3):201. Comment on: Arq Bras Oftalmol. 2013;76(1):42-4

10. Tugal-Tutkun I, Onal S, Garip A, Taskapili M, Kazokoglu H, Kadayifcilar S, Kestelyn P. Bilateral acute iris transillumination. Arch Ophthalmol. 2011;129(10):1312-9. 